\title{
The Branding Potential And Japanese Popular Culture Overseas
}

\author{
Roblyn Simeon, (E-mail: rsimeon@sfsu.edu), San Francisco State University
}

\begin{abstract}
There has been a surge in the interest in Japanese popular culture worldwide. The objective of this paper was to explore the extent to which products, images, and activities associated with Japanese popular culture are achieving the status of recognizable and sustainable consumer brands overseas. A specially designed survey was used to examine the levels of awareness, interest, and participation in Japanese popular cultural activities of individuals from different national backgrounds. Regression analysis and other statistical techniques were used to evaluate the empirical findings. The results strongly supported the view that Japanese popular culture products and services have tremendous branding potential overseas. By breaking down popular culture into recognizable components, it was possible to explore the underlying branding potential trends and gain insights into areas for further market development. This approach can be generally applied to the study of the development and marketing of popular culture products \& services.
\end{abstract}

\section{INTRODUCTION}

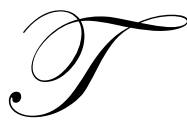

here has been a surge in the interest in Japanese popular culture worldwide. Although this interest may appear stronger among the younger generation in Europe, North America and Asia, certain contemporary aspects of this fascinating culture has attracted a strong following across many age groups in different parts of the globe. Traditionally the images and activities associated with Japanese culture have included things such as kimonos, temples, the samurai, tea ceremony, geishas, sumo, judo, and karate. In addition, since the 1970s, Japan has also come to be strongly associated with automobiles, motorcycles, and consumer electronics. However, the most recent interest in Japanese popular culture can be linked to many creative, modern, vibrant, and future oriented aspects of social life in Japan. ( Tochigi, 2003; Morishita, 2003 )

What is truly impressive is the extent to which there are multiple aspects to this recent interest in Japanese popular culture. Some of the most exciting areas include film, fashion, food, anime, manga (comics), video games, electronic toys and character goods. The strong world-wide consumer interest and marketing buzz surrounding these areas have led some to refer to this phenomenon as "Japan's Gross National Cool". This is a significantly new development in the evolution of culture related exports. Overwhelmingly, the direction has generally been from West to East. However, with this new emphasis on Eastern cultural and social developments, we see an intensifying flow from East to West. (Morishita, 2003;Barac, 2004)

One way of evaluating how cool, hip or interesting Japanese popular culture has become is to examine the commercial impact of the phenomenon inside and outside of Japan. The contents industry as it is sometimes referred to in Japan is growing rapidly as this shift from mainly hardware exports to intensified "cultural exports" accelerates. The 'contents industry' accounts for about 13 trillion yen ( $\$ 130$ billion) in annual sales and is now one of Japan's leading business sectors. It is often a surprise to many that Japanese anime accounts for over $60 \%$ of the world-wide production of cartoons. Children and young adults around the world have become loyal fans of anime such as Dragon Ball, Pokemon, Sailor Moon, Ultraman, Ultimate Muscle, Digimon, and Gundam. Recently, major advertising companies and trading houses in Japan announced that they would start promoting and aiding in the distribution of anime products. (Kishimoto, 2004; Bigge, 2001; Grey, 2000) 
Japanese pop music, TV shows and fashion trends have also been popular in Asia for a long time. However, in recent years, it is in the area of films that there have been some spectacular developments. During the same week in 2004, the number one film (The Grudge) and number three film (Shall We Dance) in the U.S. were remakes of Japanese movies. The number of other films with a strong Japanese influence has also increased dramatically. The success of movies such as The Last Samurai, Kill Bill I \& II, Lost in Translation, The Ring, Spirited Away, Godzilla, Hanabi, Zatoichi and the Twilight Samurai all point to the growing interest of Hollywood and Americans in Japanese themes. Japanese horror films (J-Horror) are a hit and some American movie studios have moved quickly to acquire the rights to remake a number of them. These developments add to the continued strong interest in Japanese anime and manga. It is not an exaggeration to say that Japanese popular cultural products could soon be recognized as strong brands with enormous commercial potential. (Morishita, 2003; Anonymous, 2003; Tamaki , 2003)

The main goal of this paper is to explore the extent to which products, images, and activities associated with Japanese popular culture might be achieving the status of recognizable and sustainable consumer brands overseas. To arrive at a better understanding of the branding dynamics in this area, there will be an examination of the levels of awareness, interest and participation of a variety of people in a number of Japanese popular cultural activities (McEnally 1999; Goodyear, 1993; Pavitt , 2000). Finally, to ascertain which overall descriptions or themes best project the branding orientation of Japanese popular culture overseas, a specially designed survey was used to capture and explore the responses of individuals from different national backgrounds. Regression analysis and other statistical techniques were used to evaluate the empirical findings.

\section{LITERATURE REVIEW \& PROPOSITIONS: INTERNATIONAL MARKETING AND THE ROLE OF CULTURE}

International marketing research has often explored the links between marketing strategy and culture in various environments. This is due to the realization that culture can have a significant impact on the effectiveness of business and marketing strategy. The different marketing research agendas that incorporate the importance of culture can roughly be divided into five areas:

1. Impact of culture on customization.

2. Global culture \& converging preferences

3. National cultural values influencing marketing practices

4. National culture and destination marketing

5. Linking subcultures \& brand development

The first perspective examines how the strategies used to customize products and services take into account different cultural demands. In marketing, we often see varied advertising approaches and positioning for different ethnic groups and regions. Product dimensions and names have also been shown to affect brand perception in different parts of the world. In this perspective, incorporating cultural preferences helps with customization and is a way of drawing closer to customers while providing localized services. (Dallmann 2001; Fitzgerald, 1998)

The second area of culture related marketing research examines how globalization interacts with consumer preferences in different parts of the world. The view here is that, with converging preferences, it is easier to use global approaches to address and influence consumers across different national markets. This is most evident in areas such as music, high fashion, sports clothing, movies, and consumer electronics. The focus here is mainly on how to penetrate different markets with standardized or global approaches despite some demands for local customization. Another aspect of this research shows how powerful global forces penetrate local markets and eventually change local preferences. In both cases, the theoretical thrust centers around explaining why similar business or marketing practices might be used in different cultural environments. (Helman and deChernatony ,1999; Lee and Lam, 1998; Hounslow, 1988; THORPE, 1999)

For those who have attempted to explain the nature of the differences across borders in marketing strategies and practices, there has been a big emphasis on applying the cultural values approach of Geert Hofstede. This third perspective often shows how the knowledge of the importance of different cultural values (power distance, 
collectivism, uncertainty avoidance and masculinity) might impact the effectiveness of the business practices and marketing strategies used in different parts of the world. (Hofstede, 1980 \& 1998; Hudson and Wadkins 1988; Keillor and Hult 1999; Gurhan-Canli and Maheswaran, 2000; Koike, 1994; Lackman, Hanson et al.,1997)

The importance of marketing a nation or a national culture is also crucial in international tourism and trade activities. In this fourth perspective, the marketing of national characteristics, location advantages, and lifestyle features are usually heavily promoted. Certain countries have been successful in projecting a desired image which directly impacts the level of tourism, trade, services and product purchases. France, for example, has fiercely defended and marketed certain aspects of its national culture. (Raviv, 2002; Pratt, 1993)

The last area of culture related market research looks at the impact of subcultures on the larger national culture as well as on popular global trends. Since subcultures are often associated with new ideas, innovative practices, and unconventional lifestyles, they often provide fertile ground for new marketing approaches and unusual branding strategies. Those in search of cool, hip and trendy developments often find them in activities and themes of subcultures. This is clearly evident in areas such as fashion and music where many dominant styles started out as the core activities of subcultures. Marketing strategies now aggressively incorporate subculture themes and products in their promotional activities. (Stuttaford, 1996; Considine, 1995)

In this paper's examination of the branding potential of Japanese popular culture overseas, we find many elements of the last two marketing perspectives. There is the general promotion of national cultural activities as well as the active world-wide interest in the dynamic and trendy subcultures in Japan. The international branding potential of popular cultural goods and activities is a growing area of research and this study should provide further insights for international marketers. (Yano,1999; Elliott, 2002; Silverberg, 1992)

For all the perspectives presented above, marketing research has shown links between an individual's level of experience with certain activities and their tendency to have a positive view of related products or services. In this examination of Japanese popular culture, there is a focus on awareness, interest and search activities and their impact on a favorable disposition towards popular culture related factors. Research has shown that friendship networks also serve to intensify the interest and search activities of individuals. Building on previous research and the perspectives above, it can be said that individuals who previously had a strong link to or a positive view of a subculture or national culture would most likely prefer brands linked to those cultural areas. (McDonald 1995; Ives, 2002; Money, Gilly et al., 1998; Usunier 1996)

The equation below summarizes the relationships among these factors. Popular culture brand potential is considered a function of awareness, interest, search and positive culture view. Based on observations above, four research hypotheses have been formulated:

Popular Culture Branding Potential $=f$ (awareness, interest, search, positive culture view $)$

H1: The greater the range of experience with popular cultural activities and products, the more likely will individuals view them as positive culture brands.

H2: The more individuals have a positive view of a subculture or a national culture, the more likely it will be that those individuals prefer the related cultural brands and products.

H3: Younger respondents are more likely to attribute positive brand orientations to Japanese contemporary cultural activities and products.

H4: The greater the cultural proximity, the more likely it will be that individuals attribute a higher positive brand orientation to popular cultural activities and products. 


\section{SURVEY DESIGN}

\section{Popular Culture Components \& Levels Of Experience.}

A survey was designed to capture the opinions and impressions of a variety of international respondents. Preliminary research indicated that it would be more effective to look at many aspects of Japanese popular culture instead of one catch-all popular culture term. Based on this research, twelve different activities or items that could represent recent Japanese popular culture were chosen. The left side of the survey (figure 1, appendix) includes items such as Japanese food, fashion, music, manga, animation, movies, TV shows, video games, martial arts, character goods, electronic toys and Buddhism. By focusing on these popular culture components, the survey was able to capture a more complete picture of the scope of interest and participation.

For each culture component, questions were asked about the respondents' level of awareness, interest and participation in Japanese popular culture activities. In addition, four columns at the top of the survey have questions that ask to what extent, on a 5 point scale, respondents agreed or disagreed with statements about Japanese popular culture and lifestyle activities ( $1=$ strongly disagree \& $5=$ strongly agree). These questions reflect different levels of experience with the Japanese popular culture components.

\section{The Branding Orientation Of Japanese Popular Culture}

For certain products and services today, their branding potential is tightly linked to their presence in the popular culture. Some market researchers have tried to gauge the level of coolness or trend setting potential of brands by measuring their references in music, movies and television. Others have focused on the extent to which young people view the new ideas and activities as interesting or trendy. The research literature often points out that strong subculture support for certain activities often precedes their successful emergence in the general marketplace. (Barac,2004; Kiehl, 2004). In examining the branding and marketing potential of Japanese popular culture, a wide variety of individuals were surveyed to find out to what extent they thought that Japanese popular culture components were interesting, trendy, cool, exotic, and innovative (appendix, figure 2: $1=$ strong disagree \& 5= strongly agree).

\section{DATA COLLECTION AND VARIABLE DEFINITIONS}

Since there has been very little research done on the link between Japanese popular culture and branding potential overseas, a new survey instrument was developed (appendix, figures $1 \& 2$ ). Fifty volunteers randomly chose the individuals who agreed to complete the survey. The completed survey was collected from 638 individuals in the San Francisco (SF) Bay Area, California. The SF Bay Area is very international and in addition to Americans in the sample, respondents came from a variety of countries in Europe, South America and Asia. Since there is an expectation of a degree of cultural similarity between Asians and Japanese, the data was divided into two main categories in our analyses: Asian Born (50\%) and Other Countries (50\%). American born respondents represented approximately $34 \%$ of the sample. The large number of young respondents accounted for $84 \%$ of the sample while females were slightly more than half at $51 \%$. Although randomly chosen, this was an acceptable distribution of respondents and it allowed the clarification of important trends in this investigation of the branding of Japanese popular culture.

\section{Dependent Variables}

The survey was designed to facilitate the examination of branding orientation of Japanese popular culture. The dependent variables all represent different descriptions of popular culture themes and orientations: interesting, trendy, cool, high quality, and innovative. By breaking the branding orientation down into these different categories, it made it possible to fully explore the subtle differences in the response for each popular culture component (figure 2, appendix). For each popular culture component, the respondents were asked to what extent (5 point Likert scale) they considered that the activity or item exhibited characteristics (cool, hip, trendy etc) that marketers could use to for popular cultural branding. Each of the first five dependent variables was created by summing responses vertically for all the twelve cultural components (figure 1, appendix). The Cronbach alphas for the first five dependent variables 
representing popular culture orientations were as follows: interesting (.86), trendy (.86), cool (.87), high quality (.87), and innovative (.86). The final variable (high cultural brand) is a combination of the scores of the first five dependent variables. The Cronbach alpha for this catch-all brand orientation variable was .94.

\section{Independent Variables}

This paper holds the view that a respondent's level of awareness, interest, and search related to Japanese popular culture should have a major impact on the how they view the branding orientation of popular culture components. Marketing research has shown that higher levels of awareness, interest and search activities related to products or services tend to be positively correlated with a favorable view of the related brands (McDonald 1995; Money, Gilly et al. 1998). The first four independent variables are directly linked to the levels of experience of the Japanese popular culture components (figure 1). Respondents were asked to what extent they were aware of, interested in and participated in the popular cultural activities. Given the importance of friendship networks, they were also asked to what extent their friends were interested in these same activities. The first four variables resulted from a summing of responses about experience levels across all the popular cultural components. The names and Cronbach alphas for these variables are: personal awareness (.84), personal interest (.86), friend's interest (.89), and personal participation (.87).

The variable intensive search behavior (alpha: .63) was created with a four-item scale that combined responses to questions about the extent to which respondents got information on Japanese popular culture from television, the internet, magazines or from friends. Since the attitude toward general Japanese cultural practices could influence the respondents view on these contemporary cultural components, we included a three-item scale called positive culture view (alpha: .62). This variable measured the extent to which the respondents generally have a positive view of Japanese cultural practices. The last three variables age, gender and national origin were all constructed as dummy variables. Respondents above 30 yrs old were coded as 1 and those younger were coded as 0 . Males were code 1 and females as 0 . Non Asian-born respondents were coded 0 and Asian-born as 1.

\section{DATA ANALYSIS AND OBSERVATIONS}

In examining the components of Japanese popular culture, it became clear that the majority of respondents show a high level of interest and awareness (figure 3). The highest possible score for each category is 25 . The category with the highest score was Japanese food. This is understandable since Japanese food has become widely accepted and popular in many capitals of the world. From a marketing perspective, it might even be considered a mature product category. The three popular culture categories that had average scores above 15 were animation, video games and character goods. These appear to be the hottest popular culture areas. Each category has a huge following of dedicated consumers around the world. Character goods, for example, do not only refer to the products of the Sanrio Company (hello kitty etc) but to the numerous product images linked to animation, film, and video game successes. Fashion, manga and electronic toys round out the popular culture components that are at the 15 point score range. These abovementioned areas appear to be the driving forces behind the explosion in interest in Japanese popular culture. What is interesting is that all the remaining categories have average scores of more than 10. Overall, this is a clear indication that the chosen components accurately reflect the concept of Japanese popular culture.

In order to explore interest, awareness and search behavior, the respondents were separated into different categories. Asian-born respondents were compared to those from other areas (U.S. etc). For all the major levels of experience, Asian-born respondents had higher means than those from other countries (table 1, appendix). The gap was widest for personal interest and friend's interest. This indicates that friendship networks were important in the respondents finding out about and appreciating Japanese popular cultural activities. There is a similar pattern for the comparison of those above and below 30 years old. Younger respondents were not only more likely to have a personal interest in Japanese popular culture but they also had friends who shared their interests (table 1, appendix). The gender gap was not very noticeable for the different levels of experience. 
Figure 3: Support for Japanese Popular Culture Components

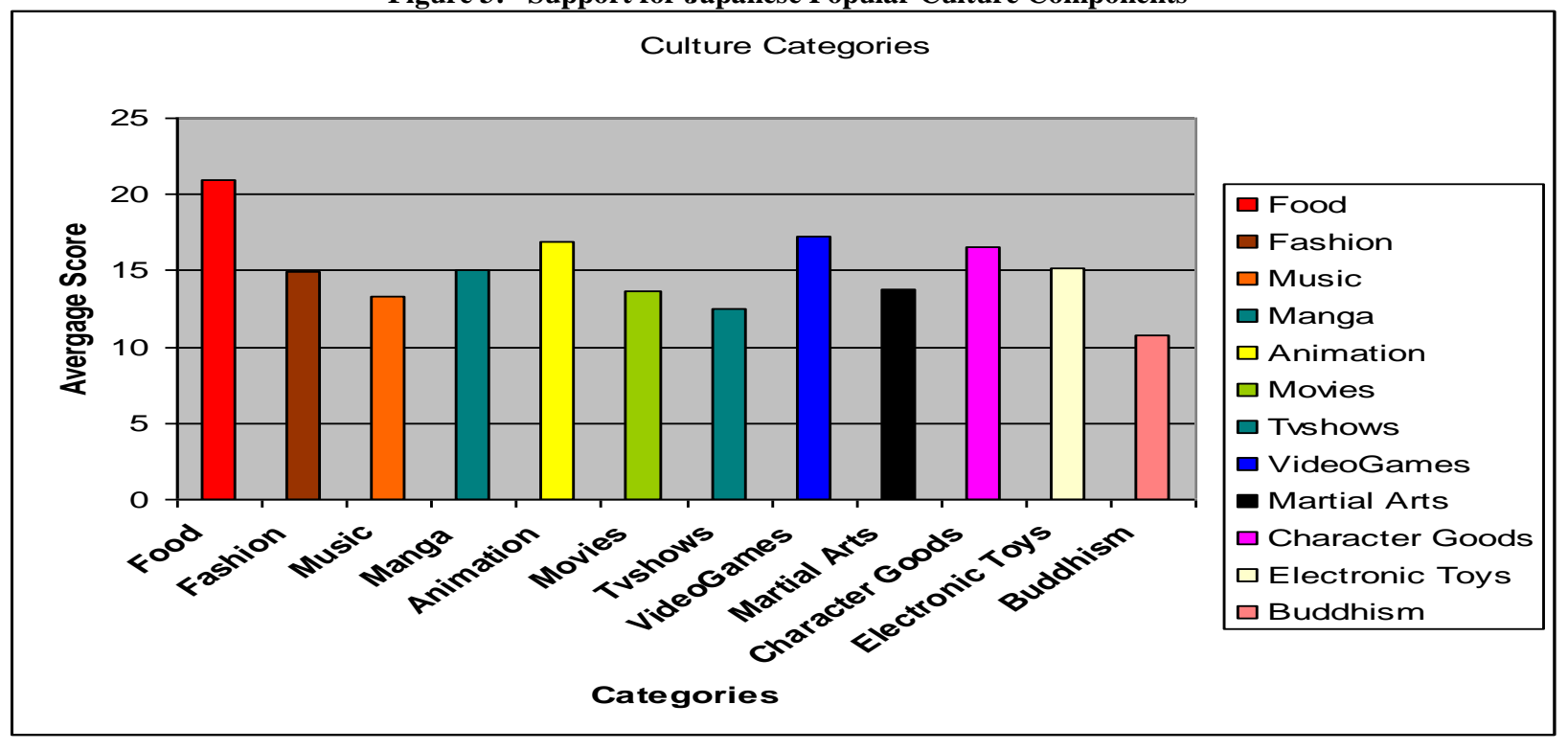

The same comparisons were used to examine the respondents' view of Japanese cultural branding orientation. Asian-born individuals, those younger than 30 yrs and female respondents were generally more likely to find Japanese popular culture to be interesting, trendy, cool, exotic, high quality and innovative (table 2, appendix). That females had higher scores on all the branding orientation themes is especially interesting. It appears that women more often than men move beyond an awareness and interest to elevate the cultural components to the level of branded product or service.

\section{Regression Analysis}

In this section, there was an examination of the impact of experience level variables, respondents' background and culture view on different aspects of cultural branding orientation (table 3). The dependent variables represent different attractive aspects of a popular culture. From music to movies, the adjectives that are often associated with growing popular support include interesting, trendy, cool, and innovative. Personal awareness, personal interest, and friend's interest all had a significant impact on our dependent variables (table 3). Market research has also indicated that product or service awareness and interest generally precede brand awareness and acceptance (McEnally 1999; Goodyear,1993).

This result provides general support for the first hypothesis stating that a wider range of experience with popular culture activities will enhance the tendency of individuals to prefer related brands. Another development which supports the first hypothesis is the significant impact of intensive search behavior on all the brand orientation dependent variables. Respondents who actively consulted magazines, television and friends for information about Japanese popular culture were more likely to have a more positive branding orientation (table 3 ).

However, after taking into account search behavior, the respondents' personal awareness and interest as well as their friends' interest, personal participation did not appear to have a significant impact on cultural branding orientation. One explanation is that only awareness and interest cover the full range of the twelve popular cultural components (figure 1). This could also indicate that these respondents will most likely become more active participants in Japanese popular cultural activities in the future. The third hypothesis was strongly supported since positive culture view had a significant impact on all the dependent variables. Those individuals that had a positive view of Japanese national cultural practices tended to think of Japanese popular culture as interesting, cool, trendy and innovative. From a marketing perspective, this result could also indicate that the global impact of national cultures and the subcultures within them are more closely linked than we might expect. 
The last two hypotheses are linked to the characteristics of the respondents. After controlling for experience levels, search behaviors and positive culture view, there appeared to be little difference between those over and under $30 \mathrm{yrs}$ old in branding orientation preferences. This could indicate that some of the popular culture activities (e.g. food, fashion, films, Buddhism) also appeal to older respondents. In the area of gender, we find good support for the third hypothesis. Female respondents were generally more likely to attribute positive branding orientations to Japanese popular culture activities and products (table 3). Given that female respondents are especially loyal and brand conscious in areas such as food, fashion and character goods, these results are not surprising. The global presence of "hello-kitty" and other Sanrio products is driven by the strong support of female consumers world wide.

Based on the regression results, the fourth hypothesis related to cultural proximity was not completely supported. In a simple comparison of means (anova) analysis, there was general support for the cultural proximity idea. However, once we control for search behavior, gender, experience levels, and positive culture view, the differences were no longer statistically significant. The final dependent variable, high cultural brand, is a combination of the scores for all the other Japanese popular culture branding orientations. The respondents with higher range of experiences (interest, awareness, and search) were all more likely to view Japanese popular culture as a high cultural brand. The results were the same for female respondents and those with initial positive view of Japanese cultural practices. An adjusted r-square of .62 indicates that this particular set of independent variables could effectively explain the high cultural brand concept.

Table 3: Japanese Popular Culture Branding Orientations

\begin{tabular}{|c|c|c|c|c|c|c|}
\hline Range of Experiences & $\begin{array}{l}\text { Interesting } \\
\text { Culture }\end{array}$ & $\begin{array}{l}\text { Trendy } \\
\text { Culture }\end{array}$ & $\begin{array}{c}\text { Cool } \\
\text { Culture }\end{array}$ & $\begin{array}{l}\text { High Quality } \\
\text { Culture }\end{array}$ & $\begin{array}{c}\text { Innovative } \\
\text { Culture }\end{array}$ & $\begin{array}{l}\text { High } \\
\text { Cultural } \\
\text { Brand }\end{array}$ \\
\hline Personal Awareness & $0.36 * * *$ & $0.41 * * *$ & $.31 * * *$ & $.33 * * *$ & $.33 * * *$ & $2.02 * * *$ \\
\hline Beta (SE) & $(.04)$ & $(.04)$ & $(.04)$ & $(.04)$ & $(.04)$ & $(.18)$ \\
\hline \multirow[t]{2}{*}{ Personal Interest } & $0.42 * * *$ & $.17 * *$ & $.33 * * *$ & $0.20 * * *$ & $.15 *$ & $1.36 * * * *$ \\
\hline & $(.05)$ & $(.05)$ & $(.05)$ & $(.05)$ & $(.06)$ & $(.25)$ \\
\hline \multirow{2}{*}{ Friend's Interest } & $0.14 * * *$ & $0.20 * * *$ & $.17 * * *$ & $.21 * * *$ & $.22 * * *$ & $.94 * * *$ \\
\hline & $(.04)$ & $(.04)$ & $(.04)$ & $(.04)$ & $(.04)$ & $(.18)$ \\
\hline \multirow[t]{2}{*}{ Personal Participation } & -0.005 & 0.0005 & 0.0004 & 0.004 & -0.0001 & 0.12 \\
\hline & $(.04)$ & $(.05)$ & $(.05)$ & $(.05)$ & $(.05)$ & $(.22)$ \\
\hline \multirow[t]{2}{*}{$\begin{array}{l}\text { Intensive Search } \\
\text { Behavior }\end{array}$} & $0.2 *$ & $.32 * * *$ & $.32 * *$ & $.22 *$ & $.31 * *$ & $1.65 * * *$ \\
\hline & $(.09)$ & $(.09)$ & $(.09)$ & $(.09)$ & $(.11)$ & $(.46)$ \\
\hline \multirow[t]{2}{*}{ Positive Culture View } & $0.27 * *$ & $.21 *$ & $.21 *$ & $.24 *$ & $.35 * *$ & $1.37 * *$ \\
\hline & $(.09)$ & $(.09)$ & $(.10)$ & $(.10)$ & $(.11)$ & $(.49)$ \\
\hline \multirow[t]{2}{*}{ Age $\quad$ (below 30). } & $-1.68^{*}$ & 0.39 & -0.46 & -0.005 & -0.17 & -1.37 \\
\hline & $(.70)$ & $(.71)$ & $(.73)$ & $(.72)$ & $(.81)$ & $(3.59)$ \\
\hline \multirow[t]{2}{*}{ Gender (female) } & $-1.17^{*}$ & $-1.69 * *$ & $-1.63 * *$ & $-1.14 *$ & $-1.35^{*}$ & $-8.04 * *$ \\
\hline & $(.51)$ & $(.51)$ & $(.53)$ & $(.53)$ & $(.59)$ & $(2.59)$ \\
\hline \multirow[t]{2}{*}{ Asian Born (vs others) } & -0.29 & -0.62 & -0.29 & -0.13 & -0.004 & -1.01 \\
\hline & $(.55)$ & $(.56)$ & $(.57)$ & $(.57)$ & (.63) & $(2.80)$ \\
\hline $\mathrm{N}$ & 638 & 638 & 638 & 638 & 638 & 638 \\
\hline Adj. R-Square & 0.61 & 0.56 & 0.58 & 0.54 & 0.46 & 0.62 \\
\hline
\end{tabular}

\section{CONCLUSION}

This empirical investigation of branding orientation of Japanese popular culture overseas provided some interesting insights. Both personal and friendship interest in and awareness of popular culture activities boosted the tendency of respondents to have a positive view of Japanese popular culture. On the other hand, direct participation in these popular culture events were not as strong a predictor of a favorable view of Japanese popular culture. This mainly indicates that although the respondents are aware of and have a positive view of the popular culture components, they have not yet directly experienced all of them. However, intensive search behavior should also be 
included to make sense of the results. This variable had a significant impact on all branding orientation variables. If one considers search behavior as a kind of participation, then it is possible to say that this aspect of personal participation is a significant predictor of those likely to have a positive view of Japanese popular culture.

By breaking down Japanese popular culture into twelve different activities or themes, this paper was able to identify the more mature aspects as well as those that are not as widespread in the market. However, it was surprising that most of the respondents showed a relatively good awareness and understanding of the popular culture components. This bodes well for the marketability of Japanese popular culture. Interest is clearly growing in many countries and this will allow Japanese firms to aggressively expand the brand awareness and eventually participation of Japanese popular culture.

This investigation looked mainly at the awareness, attitudes and behaviors of the consumers of Japanese popular culture abroad. However, there may be other factors that could aid the rapid diffusion of Japanese popular culture overseas. More research needs to be done on the type of business models used by organizations and individuals that are the producers of this cultural content. For most aspects of Japanese popular culture, the content is produced for the local Japanese market. However, because of the commercial impact and potential of many of these cultural products, there is now a conscious effort to nurture and expand the popular culture market.

Recently, many steps have been taken by the government and large corporations to make it easier to grow and sustain this marketable popular culture sector. They recognize that the "contents industry" is an important competitive advantage of the Japanese market. Trading companies, advertising agencies, movie studios, and consulting firms have decided to use more resources to promote the sector abroad. Universities have established special departments to focus on the production, marketing and diffusion of various aspects of Japanese popular culture. Companies in other countries have taken notice and we can expect more mainstream use and adaptation of Japanese popular culture products and themes. MTV's decision to launch a cell phone channel in Japan that relies heavily on the contents industry is a good example of this development. (Anonymous, 2000; Kishimoto, 2004)

Government agencies, advertising companies and even trading companies are now developing new strategies to take advantage of this huge market. In the area of animation, manga and films, there are active steps being taken to expand distribution and production activities of Japanese cultural products (Tochigi, 2003; Morishita, 2003). However, there are some dangers to the continued commercial potential of these popular culture products and activities.

In some areas, the Japanese business models and content strategies are being copied in Korea, Taiwan and China. Other Asian countries are now nurturing and expanding the activities of their music groups, anime, manga, fashion, television shows, and films. These countries have witnessed the commercial success of Japanese popular culture and are actively trying to link their cultural brands to some of the same areas. Recently, Chinese, Taiwanese and Korean singers have become popular in Japan and elsewhere in Asia. The Korean television dramas are being actively exported to other countries in Asia and anime production is growing rapidly in other parts of Asia. It will require unique branding strategies for Japan to maintain its lead and benefit from this movement from East to West.

This paper provides one approach for studying the international branding potential of popular cultural good and activities. Branding potential of popular culture is a function of several factors. This research showed that it is important to consider the components of popular culture activities as well the levels of experience with those activities. Future research might find it interesting to further examine the role of friendship networks in the rapid diffusion of popular culture trends. In terms of cross border developments, more research also needs to be done to understand how the same phenomenon can be interpreted and experienced differently but still have a tremendous impact in different environments.

\section{REFERENCES}

1. Anonymous (June 2, 2000). MTV to launch videos by mobile phone only in Japan. AFP. Tokyo, Japan: http://www.mobilemediajapan.com.

2. Anonymous (Oct. 6, 2003). Japan's latest attractions. The Nikkei Weekly. Tokyo, Japan: 31. 
3. Barac, V. (Sep 20, 2004). The slippery nature of cool. Marketing 109(30): 27.

4. Bigge, R. (May 28, 2001). Gimme that old brand religion: in today's consumer culture, product names have become more identifiable than apostles. Marketing Magazine 106(21): 10.

5. Considine, P. (Sep 22, 1995). Star quality changes commercial direction. Marketing Week 18(27): 26.

6. Dallmann, K. M. (2001). Targeting women in German and Japanese magazine advertising: A difference-indifferences approach. European Journal of Marketing 35(11/12): 1320.

7. Elliott, S. (Feb 19, 2002). Once again, 20 questions on campaigns, marketing, the media and popular culture. New York Times: C.10.

8. $\quad$ Fitzgerald, K. (Aug 24, 1998). Music makes campaigns more meaningful to Latinos. Advertising Age 69(34): S26.

9. Goodyear, M. (May 1993). Reviewing the concept of brands and branding. Marketing and Research Today 21(2): 75.

10. Grey, R. (Sep 21, 2000). Turning Japanese. Marketing: 34.

11. Gurhan-Canli, Z. and D. Maheswaran (Aug 2000). Cultural variations in country of origin effects. JMR, Journal of Marketing Research 37(3): 309.

12. Helman, D. and DeChernatony, L. (Apr 1999). Exploring the development of lifestyle retail brands. The Service Industries Journal 19(2): 49.

13. Hofstede, Geert (1980). Culture and Organizations. International Studies of Management \& Organization. V. 10, Issue 4: 15 .

14. Hofstede, Geert (1998). Identifying Organizational Subcultures: An empirical approach. The Journal of Management Studies. Volume 35, Issue 1: 1.

15. Hounslow, S. (Jul 28, 1988). Why U.S. Lagers Aren't Refreshing These Here Parts. Marketing: 30.

16. Hudson, L. A. and M. Wadkins (1988). Japanese Popular Art as Text: Advertising's Clues to Understanding the Consumer. International Journal of Research in Marketing 4(4): 259.

17. Ives, N. (Nov 6, 2002). The odd embrace of marketing and anti-establishment music. New York Times: C.3.

18. Keillor, B. D. and G. T. M. Hult (1999). A five-country study of national identity Implications for international marketing research and practice. International Marketing Review 16(1): 65.

19. Kiehl, S. (Aug 25, 2004). The art of brand-name dropping; Marketing magic or a hip-hop hit? It's hard to tell, but manufacturers aren't complaining. Los Angeles Times: E.5.

20. Kiehl, S. (Sep 5, 2004). Brand names get hip-hop, pop boost. The Sunday Patriot - News: J.07.

21. Kishimoto, S. (June, 2004). Shoring Up Japan's Content Industry. Japan Echo. Tokyo, Japan: 19-23.

22. Koike, S. (Winter 1994). Perspective: Predictable Japanese - An analysis of their interdependent relationships. The Journal of Language for International Business 5(2): 37.

23. Lackman, C., Hanson, D. \& Lanasa, J. (Winter 1997). Social relations in culture and marketing. Journal of Marketing Theory and Practice 5(1): 144.

24. Lee, G. B. and S. S. K. Lam (Dec 1998). Wicked cities: Cyberculture and the reimagining of identity in the 'non-Western' metropolis. Futures 30(10): 967.

25. McDonald, W. J. (1995). American versus Japanese consumer decision making: An exploratory crosscultural content analysis. Journal of International Consumer Marketing 7(3): 81.

26. McEnally, M. and DeChernatony, L. (1999). The Evolving Nature of Branding: Consumer and Managerial Considerations,. Academy of Marketing Science Review 1999: 1.

27. Money, R. B., M. C. Gilly, et al. (Oct 1998). Explorations of national culture and word-of-mouth referral behavior in the purchase of industrial services in the United States and Japan. Journal of Marketing 62(4): 76.

28. Morishita, K. (Nov. 24, 2003). Global marketing warms to national cool. The Nikkei Weekly. Tokyo, Japan: 3.

29. Morishita, K. (Nov. 24, 2003). Pop-culture ambassadors explain art of attraction. The Nikkei Weekly. Tokyo, Japan: 3 .

30. Pavitt, J. (Oct 19, 2000). The art of marketing. Marketing: 40.

31. Pratt., S. (May 13, 1993). Foreign flavors A mammoth trade show sees international food companies vying for space on grocery shelves. Chicago Tribune (pre-1997 Fulltext): 2.

32. Raviv, Y. (Apr 30, 2002). National Identity on a Plate. Palestine - Israel Journal of Politics, Economics, and Culture 8(4): 164.

33. Silverberg, M. (Feb 1992). Constructing the Japanese Ethnography of Modernity. The Journal of Asian Studies 51(1): 30. 
34. Staff, R. R.-o. t. O. (Dec 14, 1994). Going Glocal. The Oregonian: B.01.

35. Stuttaford, G. (Jun 10, 1996). Nonfiction -- Relentless: The Japanese Way of Marketing by Johny Johansson and Ikujiro Nonaka. Publishers Weekly 243(24): 83.

36. Tamaki, T. (Oct. 6, 2003). South Korea relations warm up as interest rise in things Japanese. The Nikkei Weekly. Tokyo, Japan: 29.

37. Thorpe, V. (Jun 13, 1999). Focus: Masters of the arts; The British aren't coming. They've arrived The rebellious streak in all circles of British art is winning applause across the globe - but only when it's allied to real talent. The Observer: 021.

38. Tochigi, M. (Dec. 8, 2003). Japan's Hot New Export: TV Shows. The Nikkei Weekly. Tokyo, Japan: 31.

39. Usunier, J.-C. (Winter 1996/1997). Atomistic versus organic approaches. International Studies of Management \& Organization 26(4): 90.

40. Yano, C. R. (Aug 1999). The Worlds of Japanese Popular Culture; Gender, Shifting Boundaries and Global Cultures. The Journal of Asian Studies 58(3): 848.

\section{Appendix}

Figure 1: Levels of experience of Japanese popular culture components

\begin{tabular}{|c|c|c|c|c|}
\hline $\begin{array}{l}\text { Japanese Popular Culture } \\
\text { \& Lifestyle Activities } \\
\text { (1-5 Scale) }\end{array}$ & $\begin{array}{l}\text { I am aware that these } \\
\text { Japanese things are } \\
\text { popular } \\
\text { (1 to 5) }\end{array}$ & $\begin{array}{l}\text { I am also interested } \\
\text { in these Japanese } \\
\text { things } \\
\text { (1 to 5) }\end{array}$ & $\begin{array}{l}\text { I have friends who } \\
\text { are interested in } \\
\text { these Japanese things } \\
(1 \text { to5) }\end{array}$ & $\begin{array}{l}\text { I have actively } \\
\text { experienced or spent } \\
\text { money on these } \\
\text { things } \\
(1 \text { to } 5)\end{array}$ \\
\hline \multicolumn{5}{|l|}{ Japanese Food } \\
\hline \multicolumn{5}{|l|}{ Japanese Fashion } \\
\hline \multicolumn{5}{|l|}{ Japanese Music } \\
\hline \multicolumn{5}{|l|}{ Japanese Manga(comics) } \\
\hline \multicolumn{5}{|l|}{ Japanese Animation } \\
\hline \multicolumn{5}{|l|}{ Japanese Movies } \\
\hline \multicolumn{5}{|l|}{ Japanese TV Shows } \\
\hline \multicolumn{5}{|l|}{ Japanese Video Games } \\
\hline \multicolumn{5}{|l|}{ Japanese Martial Arts } \\
\hline \multicolumn{5}{|l|}{$\begin{array}{l}\text { Japanese Character } \\
\text { goods(ex. Hello Kitty) }\end{array}$} \\
\hline \multicolumn{5}{|l|}{$\begin{array}{l}\text { Japanese electronic Toys } \\
\text { (e.g. Aibo, Tamagochi) }\end{array}$} \\
\hline Japanese Buddhism & $\downarrow$ & & & \\
\hline
\end{tabular}

Table 1: Exploring Japanese Popular Culture Awareness \& Participation

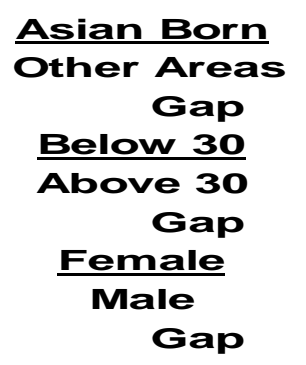

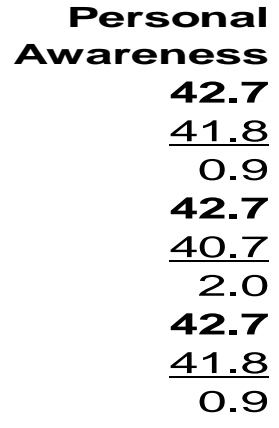

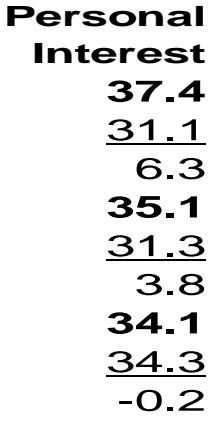

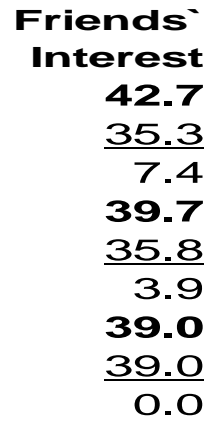

Personal Participation 32.9 26.7

6.2

30.6 27.6

3.0 29.4 30.3

$-0.9$ 
Figure 2: The branding orientation of Japanese popular culture components

\begin{tabular}{|c|c|c|c|c|c|c|}
\hline (1-5 scale) & $\begin{array}{l}\text { It is } \\
\text { interesting }\end{array}$ & It is Trendy & $\begin{array}{l}\text { It is } \\
\text { Cool }\end{array}$ & $\begin{array}{l}\text { It is } \\
\text { Exotic }\end{array}$ & $\begin{array}{l}\text { It has a high } \\
\text { quality image }\end{array}$ & $\begin{array}{l}\text { It is inno- } \\
\text { vative }\end{array}$ \\
\hline Japanese Food & & & & & & 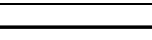 \\
\hline Japanese Fashion & & & & & & \\
\hline Japanese Music & & & & & & \\
\hline Japanese manga (comics) & & & & & & \\
\hline Japanese Animation & & & & & & \\
\hline Japanese Movies & & & & & & \\
\hline Japanese TV Shows & & & & & & \\
\hline Japanese Video Games & & & & & & \\
\hline Japanese Martial Arts & & & & & & \\
\hline $\begin{array}{l}\text { Japanese Character goods } \\
\text { (e.g. Hello Kitty) }\end{array}$ & & & & & & \\
\hline $\begin{array}{l}\text { Japanese electronic Toys } \\
\text { (e.g. Aibo, Tamagochi...) }\end{array}$ & & & & & & \\
\hline Japanese Buddhism & & & & & & \\
\hline
\end{tabular}

Table 2:

\section{Exploration of Japenese Otture Branding Oientation}

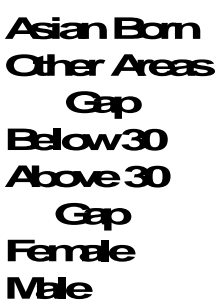

Gap

\begin{tabular}{cc}
$\begin{array}{c}\text { Interesting } \\
\text { athre }\end{array}$ & $\begin{array}{c}\text { Trendy } \\
\text { atture }\end{array}$ \\
41.7 & 40.3 \\
$\mathbf{3 7 . 7}$ & $\underline{37.0}$ \\
$\mathbf{4 0}$ & $\mathbf{3 . 3}$ \\
$\mathbf{4 0 . 0}$ & 39.2 \\
$\mathbf{3 8 . 6}$ & $\underline{36.1}$ \\
$\mathbf{1 . 4}$ & $\mathbf{3 1}$ \\
$\mathbf{4 0 . 4}$ & 39.8 \\
\hline $\mathbf{3 8 . 9}$ & $\underline{37.5}$ \\
\hline
\end{tabular}

Cod
athre
40.3
$\frac{36.0}{43}$
387
36.0
27
39.1
$\frac{37.1}{20}$

\begin{tabular}{cc}
$\begin{array}{c}\text { High } \\
\text { Qulity }\end{array}$ & $\begin{array}{c}\text { Innovative } \\
\text { alture }\end{array}$ \\
41.2 & 40.6 \\
37.2 & $\underline{36.7}$ \\
\hline 4.0 & 39 \\
39.8 & 39.2 \\
36.9 & 36.6 \\
\hline 29 & 26 \\
40.0 & 39.6 \\
\hline 38.5 & 37.8 \\
1.5 & 1.8
\end{tabular}




\section{NOTES}

